\title{
Eko’nun Yalnızlığı: Çağdaş Ses Sanatında Yalnızlık Teması
}

\author{
Echo's Loneliness: Loneliness as a Theme in Contemporary Sound Art \\ Engin Esen \\ Dr. Öğr. Üyesi, Hacettepe Üniversitesi Güzel Sanatlar Fakültesi Resim Bölümü \\ email: enginesen00@gmail.com (DORCID ID: https://orcid.org/0000-0003-3169-3084
}

Atıf (APA 6)/To cite this article

Esen E. (2019). Eko'nun yalnızlığı: çağdaş ses sanatında yalnızlık teması. Atatürk Üniversitesi Güzel Sanatlar Enstitüsü Dergisi, $43,95-104$. doi: https://doi.org/10.35247/ataunigsed.559996

Makale Gönderim Tarihi/Received: 02/05/2019

Makale Kabul Tarihi/Accepted: 01/10/2019

Makale Yayın Tarihi/Published: 26/10/2019

Review Article/Derleme Makalesi

\section{Öz}

Ovidius'un "Dönüșümler" adlı eserinde geçen Narkisos ve Eko'nun hikayesinde aşkına karşılık bulamayan bir peri kızı olan Eko ve kendi görüntüsüne âşı olan Narkisos adlı iki karakterin dönüșümü anlatılmaktadır. Bu hikâye yalnızlık temasını işlemis olup mitin kahramanlarından Eko sesi, Narkisos ise görüntüyü temsil etmektedir. Burada Narkisos kaynak görüntü ve bir yüzeye yansıyan imgesini temsil ederken, Eko ise kaynağından uzaklaşmış, bedenini terk etmiş, yabancılaşmış ve yalnızlaşmış bir ses olarak tanımlanabilir. Yirminci yüzyılda ses kayıt teknolojisinin ortaya çıkmasıyla birlikte sesler ve onları çıkaran kaynaklar birbirlerinden ayrılmaya başlamıştır. Sesleri çıkaran nesnelerin fiziksel olarak mekânda bulunmaksızın seslerinin çalınabilmesi ve manipülasyonun mümkün hale gelmesi sanatçlar tarafından sesler ve görüntülerin birbirinden bağımsız olarak yeni ilişkiler kurmasını sağlamıştır. Böylece ses ve görüntünün ayrılması düşüncesi 1960'li yıllardan başlayarak Batı sanat ortamında Ses Sanatı adı verilen bir üretim mecrasını ortaya çıkarmıştır. Bu çalışma Narkisos ve Eko mitinden hareketle, kaynak imge ve dönüșüme uğrayan sesleri doğrultusunda belirli çağdaş ses sanatı yapıtlarında yalnızlık temasının ne şekilde incelendiğine ilişkin bir bakıș açısı sunmayı hedeflemektedir.

Anahtar kelimeler: Eko, Ses, Ses Sanat1, Ses Enstalasyonu, Ses Sanatı ve Yalnızlık, Eremosen, Yalnızlık Çă̆ı

\begin{abstract}
The story of Narcissus and Echo in Ovid's "Metamorphoses", recounts the transformation of two characters, Echo, a nymph who cannot find his love, and Narcissus who falls in love with his own image. The story revolves around the theme of loneliness in which Echo represents the sound and Narcissus represents the image. Hereby, Narcissus represents the source image and the image reflected on a surface, while Echo can be defined as an alienated and lonely voice that has moved away from its source, abandoned its body. With the advent of sound recording technology in the twentieth century, sound and the source started to be separated from each other. The fact that the sounds and the objects that make the sound were able to be played without the physical presence of the object and the manipulation enabled the artists to establish new relationships between the sounds and images that are independent of each other. Thus, the idea of separation of the sound and image, starting from the 1960s in the Western art environment created a production medium which is called the Sound Art. This study aims to provide a perspective on how the theme of loneliness is examined in certain contemporary sound art works in accordance with the source image and transformed sounds based on Narcissus and Echo myth.
\end{abstract}

Keywords: Echo, Sound, Sound Art, Sound Installation, Loneliness and Sound Art, Eremocene, the Age of Loneliness

\section{Giriş}

İnsansı atalarımızın yavaş yavaş tarih sahnesinden silinmesi ve modern insan olan Homo Sapiens Sapiens'in yaklaşık yetmiş bin yıl önce ortaya çıkmasıyla birlikte türümüzün kültür tarihi başlamıştır. Modern insanın ortaya çıkışında yalnız olmadığı, aynı türden ataları olan Neandartal gibi diğer türlerle bir arada yaşadığı da bilinmektedir. İnsan ortaya çıktığı anda kısıtlı bir çevreyi başka yaşam formlarıyla paylaşmasına rağmen, günümüzde varlık alanını yeryüzünün neredeyse tamamına yaymayı başarmış, büyük ölçüde diğer canlı formlarını da kendi ihtiyaçları doğrultusunda kontrol edebilecek bir hakimiyete ulaşmıştır. Kuşkusuz bu başarıyı oluşturan sebeplerden birisi türümüzün yalnızca alet icat edecek ve kullanacak zekaya sahip olması değil, aynı zamanda olağanüstü esnek bir yapıya sahip dil kullanabilme yeteneğidir (Harari, 2012, s. 35). Bu yeteneği dolayısıyla insan etrafındaki dünya hakkında devasa miktarda bilgiyi algılayabilmekte, depolayabilmekte ve iletebilmektedir. Bir tür olarak bu kabiliyetimizin kaynağı sosyal bir canlı olmamızdan gelmektedir. Bu sosyal iş birliği hayatta kalmak ve türün devamını sağlamak için kritik öneme sahiptir.

Türümüzün ortaya çıkıp günümüze gelişi yalnızca fiziksel bir dönüşümün sonucu değil aynı zamanda bilişsel olarak gerçekleşen bir devriminin de sonucudur. Bu süreçte ortaya çıkan bir diğer unsur da dili, tehlikelerden korunmak ya da yemek bulmak gibi yalnızca pratik bilgi aktarımı sağlamanın dışında var olmayan şeyler hakkındaki bilgilerin aktarımı için de kullanmaktır. Bilindiği kadarıyla bir tür olarak yalnızca insan hiç görmediği, dokunmadığı veya koklamadığı varlıklar hakkında konuşabilmektedir (Harari, 2012, s. 37). Bu bağlamıyla kurgulayarak bir anlatı yaratma ve bu anlatıya inanabilme özelliğiyle Homo Sapiens, yalnızca küçük gruplar halinde organize olabilmenin de ötesine geçerek on binlerce kişiden oluşan şehirler kurabilmiş ve milyonlarca kişinin bir arada yaşadığı ülkeler yaratmayı başarmıştır. Kültür tarihimiz içinde klanlar oluşturmak, şehirler kurmak, ibadethaneler inşa etmek ve devletler yaratmak, yönetim sistemleri geliştirmek ve sanatsal üretim yapmak gibi geniş çaplı iş birliği ve iletişime dayanan tüm bu süreçler insanın hayal gücünde yarattığı mitlere birlikte 
inanabilmesinin bir sonucudur. Tüm bu kabiliyetleriyle düşünüldüğünde insan yalnızca hayatta kalmak için değil her anlamda kendisini var edebilmek için başka insanların varlı̆̆ına ihtiyaç duymaktadır. İnsanın kendisinden başkalarına olan ihtiyacı yalnızca kendi türüyle de sınırlı değildir, evcil ve vahşi hayvanlar, bitkiler ve hatta günümüz yüksek teknolojili cihaz ve yazılımları kısaca insanın kendi varlığı dışında kalan tüm varlıklarla karşılıklı etkileşimi, insan yaşamının vazgeçilmez bir parçasıdır. İnsanın kendi dışındaki varlıklarla kurduğu bu gündelik etkileşim kendi varlığına ayna tutar ve insanda yaşadığı ve var olduğu bilincini hatırlatır.

Elbette ki özgür iradeye sahip ve bilinçli tercihlerini yapan bir insan için yukarıda açıklanan durumların tam karșıtı da geçerlidir. İnsan kalabalıklar içinde olduğu kadar yalnız bir varlıktır aynı zamanda. Yalnızlık kavramı en yalın şekliyle bireyin çevresinde etkileşim kuracak hiçbir varlığın bulunmaması durumudur. İnsan kabiliyetleri ve iradesi ölçüsünde kendisinden başka hiçbir türdeşine ihtiyacı olmadan da varlığını sürdürebilir. Günümüz toplumlarında varlık gösteren siyasi ideolojileri, ekonomik sistemleri, ticaret ağlarını, kent yaşamını ve insanla iliş̧isi bulunan olası tüm yapıları reddeden, alternatif bir duruş sergileyerek doğada tek başına yaşamını sürdüren insanların varlığı bilinmektedir. Bu haliyle düşünüldüğünde yalnız olmak düşüncesi bireysel bir tercih olarak ortaya çıkmaktadır. Ancak insanın yalnızlığı sadece bireysel bir seçim olmanın ötesinde olup, yaşam serüveni içinde insanın yalnızlığına sebep olabilecek koşullar kiş̧nin iradesi dışında da gelişebilmektedir. Bu türden yalnızlıklar çoğunlukla, sevilen bir varlığın yitimi, düşünsel olarak bir gruba ait olamamak, duygusal olarak yalnız hissetmek gibi yaşamın akışında şekillenen bazı durumlardır. Burada değinildiği haliyle beklenmedik bir şekilde ortaya çıkabilecek ya da bireysel irade sonucu ortaya çıkan yalnızlık dışında varoluş̧̧uluk düşüncesi bağlamında ele alınabilecek bir yalnızlık kavramı da bulunmaktadır. Kabaca varoluşçuluğun yalnızlığı algılayış biçimi, insanın özden yoksun bir şekilde dünyaya bırakılmışlığıyla alakalıdır. Kalınbayrak (2011)'e göre insan, öncelikle sadece vardır. Özden yoksun varlığına anlam katmak için yaşayacaktır. Bunun için önce kendisinin diğerlerinden ayrı bir varlık olduğunu fark etmesi gerekir (s. 9).

İnsan yaşamı kesintisiz devam eden bir deneyimler dizisidir, bu akış içinde gerçekleşen yalnızlık durumları da kaçınılmaz birer deneyim olmaktadır. Bu sürecin doğal bir çıktısı da deneyimin başka insanlara aktarılmasıdır, insanlık ve kültür tarihinin tamamının insan deneyimi ve bu deneyimin başka insanlar ile paylaşılması üzerine kurulu olduğu da ifade edilebilir. Halmos (1969), Solitude and Privacy adlı kitabında bu arzunun bir ihtiyaç olduğundan bahseder: "Tecrübeyi paylaşmak, yakın arkadaşlık ve yüz yüze iş birliği içinde verilen emek, insanın her zaman başlıca ve yaşamsal ihtiyacı olmuştur" (s. 1). Bu anlamda düşünüldüğünde, deneyimin kişiler arasında paylaşılması yaşamın anlamlandırılmasında bir arada olmanın önemini vurgulamaktadır. "Ancak birileriyle ya da bir şeylerle, yani dünyasıyla birlikte var olarak kendisini algılayabilen ve yaşamına anlam verebilen bir varlık olan insan" (Gençtan, 1996, s. 23). Bazen sadece orada olduğunun bilinmesi için bile başka birine ihtiyaç duyabilir, 'Ben de oradaydım' diyebilmenin garantisi, başkasının da orada olmasıdır, bu durumda yalnızlık, insanın diğerleriyle birlikte yaşıyor olduğu kesinliğine dayanır (Kalınbayrak, 2011, s. 2).

Bir deneyim olarak yalnızlığı paylaşılma yollarından birisi de kuşkusuz sanattır. Caspar David Friedrich'in The Sea of Fog, (1818), Edward Munch'un Scream, (1893), Edward Hopper'ın Automat, (1927) gibi eserleri plastik sanatlar alanında yalnızlık kavramının işlendiği yapıtlardan sadece bir kaçıdır. Yalnızlık bir kavram olarak sanatta başlı başına bir konu olduğu gibi yapıtların, yaratım ve üretim aşamalarında da ortaya çıkan bir durumdur. $\mathrm{Bu}$ açıdan düşünüldüğünde ortaya çıkan yapıtlardaki yalnızlık kavramı son derece bireysel ve göreceli olmak durumundadır. Ayrıca, yaratım süreci içerisinde görülen yalnızlık durumu, bir kurgu gerçeklik oluşturmak, bu kurguyla ilişkili biçimi ve dili şekillendirmek gibi eylemlere olanak sağlayarak sanatsal üretimin bir tamamlayıcısı olarak karşımıza çıkmaktadır. Bu bağlamda yalnızlığın hem bir tema hem de sanatçının deneyimlerinin aktarımını sağlayan bir olgu olduğu ifade edilebilir.

Yukarıdaki bilgilerden hareketle insanın doğası gereği hiç tanımadığı yabancılarla bile güçlü sosyal ilişkiler kurabilecek bir yapıda olduğu ancak, yaşam serüveni içinde çevresindeki insanlarla olan iletişim ve etkileşiminin bilinçli ya da istemsizce kesintiye uğrayarak tek başına kaldığı görülmektedir. Bu çalışmada da benzer bir biçimde insanın yaşam deneyimi içinde nasıl yalnız kaldığını işleyen mitolojik bir anlatı olan Narkissos ve Eko mitinden yola çıkarak, hikayedeki kahraman Eko'nun yalnızlığına değinilmiştir. Hikâyedeki haliyle Eko'nun uğradığı dönüşüm sonucu bedenini terk etmiş ve yalnızlaşmış bir ses olduğu fikri açıklanmıştır. Terminolojik bir bilgi olarak eko kavramıyla ses ortamının imge aktaran bir araca dönüşmesi, ses - kayıt ve manipülasyonu bağlamında bir ifade aracı olan ses sanatı pratiğine değinilmiş, çağdaş ses sanatı içinden hem tema olarak yalnızlığı işleyen hem de ekonun yapısal bir eleman olarak kullanıldığı üç ses enstalasyonu incelenmiştir. Bu çalışmalarda işlenen yalnızlık teması ortak olmakla birlikte yalnızlık ölçekleri kişisel deneyimden başlayarak küresel ölçekli bir yalnızlığa doğru genişlemiş ve bu bağlamda bireysel bir yalnızlık hikayesinin ișlendiği Susan Philipsz'in Lowlands, toplumsal yalnızlığın ve yabancılaşmanın ele alındığı Anke Eckardt'ın, Between $|Y o u|$ and $|M e|$ ve bir tür olarak insanın dünya üzerinde yalnızlaşmasını konu edinen Embodied Media kolektifinin Eremocene adlı yapıtları değerlendirilmiştir. 


\section{Yöntem}

Araştırma Betimsel modele dayalı nitel bir araştırmadır. Buna dayalı olarak alanyazın (literatür) taraması yapılmış ve yalnızlık kavramı ve bu kavramın günümüz ses sanatı alanındaki örnekleri farklı kaynaklardan beslenerek metinsel olarak ortaya konulmaya çalışılmıştır. Kapsamlı biçimde içerik taraması gerçekleştirilmiş, elde edilen veriler ışığında veriler somutlaştırılmış ve okuyucuya sunulmuştur. Ek olarak, yalnızlık kavramının farklı sanatçılara göre değişen içerik ve bağlamlarda ele alınan yapıtları örneklerle açıklanmaya çalışılmıştır.

\section{Bulgular ve yorum}

\subsection{Narkissos ve Eko: Eko'nun yalnızlığı}

Narkissos ve Eko'nun hikayesi Ovidious, Conon, Longus ve Pausanias gibi Yunan ve Latin yazarlar başta olmak üzere pek çok yazar tarafından tekrar tekrar işlenmiş mitolojik bir aşk ve yalnızlık hikayesidir. Başta İngiliz, Alman ve Fransız edebiyatçılar olmak üzere bu hikâye zaman zaman farklı içeriklerde zaman zaman da ufak değişiklikler yapılarak ele alınmıştır. Louise Vinge'e ait The Narcissus Theme in Western Literature up to the Early 19th Century (Yörükan, 2000, s. 252) adlı eser Batı'nın edebiyat alanında bu hikâyeye yönelttiği ilgiyi açıkça göstermektedir. Sanatçıların bu mite olan ilgisi yalnızca edebiyat ile sınırlı değildir elbette, Caravaggio, Nicolas Poussin, Claude Lorain, John William Waterhouse, Vasily Kandinsky, Max Ernst ve Salvador Dali gibi pek çok sanatçı bu konuyu yapıtlarıyla görselleştirmişlerdir. Müzik ve sahne sanatları alanında ise Christoph Willibald Gluck, Ryan Wigglesworth, Stuart MacRae tarafından bu hikâye opera, senfoni ve dans biçiminde yorumlanmıştır.

Yunan Mitolojisinde Aşk adlı kitabında Yörükan (2000)'ın aktardığı üzere Narkissos öyküsünün Conon (Diegesis/Narrationes, 24) da yer alan şekli ile Pausanias'ın (Guide to Greece, IX, 31, 6) mitolojik havası kaybolmuş ve Eko'nun yer almadığı versiyonları bulunmaktadır (s. 258). Bu sebeple bu çalışma için ele alınan Narkissos ve Eko'nun hikayesi Ovidious’un Dönüşümler adlı eserinin III. kitabında ve 339.-510. dizeleri arasında yer alan versiyonudur. Bu hikâyeye göre Irmak-tanrı Kephisos ile Liriope isimli perinin cinsel birleşmesinden çok güzel bir erkek çocuğu dünyaya gelmiştir ve Liriope oğluna Narkissos adını vermiştir. Göz alıcı güzelliğe sahip oğlunun uzunca bir yaşamı olup olmayacağını öğrenmek isteyen Liriope, Theresiaslı bir kâhine danışır. Kâhin "yaşayabilir ama, kendi kendisini tanımaya kalkmazsa" gibi belirsiz bir cevap verir. Hikâyenin ilerleyen kısımlarında on altı yaşına gelen Narkissos büyüleyici bir güzelliğe sahip ancak, kibirli ve kendini çok beğenmiş bir kişiliğe sahip olur. Narkissos bir gün bir geyik avlamak için ormanın derinliklerine kadar ulaşır ve orada bulunan Eko isimli bir peri onu görüp bu yakışıklı gence büyük bir aşk ile tutulur. Hikâyenin ikinci kahramanı olan Eko, Zeus'un karısı Hera tarafından lanetlenmiştir bu yüzden de konuşması kısıtlanmıştır, bu lanete göre Eko yalnızca işittiği cümlelerin son kelimesini tekrar edebilecek bir hale dönüştürülmüştür.

Eko aşkına ulaşmak ve kendisini gösterebilmek için Narkissos'u takibe başlamıştır, Eko üzerindeki lanetin etkisiyle ses çıkartamadığı için Narkissos'un ona seslenmesini sağlamak amacıyla dikkatini çekmeye çalışmış ve başarılı da olmuştur. Eko'yu işiten Narkissos “Orada birileri mi var” diye sormuş ve Eko da lanetin etkisiyle yalnızca son kelimeyi tekrar edip "Var" cevabını verebilmiştir. Bir süre boyunca gerçekleşen diyalog sonucunda Eko, aşk yaşamak umuduyla cesaretini toplayabilmiş ve Narkissosun boynuna sarılmıştır, ancak Narkissos kendini beğenmişliğinin de etkisiyle Eko'yu "Çek ellerini üzerimden, senin bana sahip olmandansa ölmeyi yeğlerim" diyerek bir kenara savurmuş ve yoluna devam etmiştir. Bu biçimde bir reddedilme ve küçük düşmenin bir sonucu olarak Eko, ormanın derinliklerinde ve mağaralarda gizlenerek aşk acısını bir başına yaşamaya başlamıştır. Günler geçtikte yemeden ve içmeden kesilen Eko, en sonunda güzelliğini ve bedenini de yitirerek geriye sadece sesi kalacak şekilde bir yok oluşa sürüklenmiştir. Yörükan'ın (2000) aktardığı şekliyle, bundan böyle Eko yankı adı verilen sese dönüşmüştür. Seslendikçe sesimize cevap veren, bize hala yaşıyorum diyebilmek için sesimize aynı sesle karşılık veren bir ses haline gelmiştir (s. 255).

Hikâyenin geriye kalan kısmı ise Narkissos'un başına gelenler ile ilgilidir. Hikâyede aşkına karşılık bulamayan ve Eko'nun düştüğü hale üzülen kişiler, Narkissos'un cezalandırılması için intikam tanrısı Nemesis'e dua etmişlerdir. Kendisine yöneltilen bedduaları kabul eden Nemesis kibirin, kendini beğenmişliğin ve başkalarını hor görmenin cezasını Narkissos'a vermiştir. Yine bir av peşinde koşan Narkissos yorgunluğunu ve susuzluğunu gidermek için bir pınar kenarında durmuş ve su içmek için su birikintisine doğru eğilmiştir. Tam da bu anda Nemesis Narkissos'un cezasını vermiş, suda kendi yansımasını gören Narkissos kendisine karşı bir kara sevdaya tutulmuştur. Gözlerini kendi suretinden bir an olsun ayırmayı başaramayan Narkissos açlık ve yorgunluktan kaynaklı olarak bir çöküşe gitmiş ve orada ölmüştür. Hikâyeye göre Narkissos’un bedeni burada bir nergis çiçeğine dönüşmüştür.

Eko ve Narkissos'un hikayesi yalnızca bir kara sevda hikayesi değildir aksine, toplumsal kodlar dahilinde "ne ekersen onu biçersin" türünde belirli ahlaki durumların simgesel ifadesi olduğu ölçüde, yalnızlık ve hesaplaşma gibi psikolojik ve sosyal konular yönünden de derinlikli bir anlatıya sahiptir. Bu mitos derinlemesine düşünüldüğü ölçüde bir takım doğa olaylarını aktardığı gibi bazı sanat geleneklerini de sembolize ettiği görülmektedir. Bu hikâyede Eko sesi ifade ederken Narkissos ise görüntüyü temsil etmektedir. Buradan hareketle Narkissos'un 
doğası gereği görüntüyü sahiplenen plastik sanatlar ve hareketli görüntüye dayalı olan video ve sinema gibi biçimleri temsil ettiği, Eko'nun ise ses ile ifadeyi sahiplenen müzik ve performans gibi ifade biçimlerini temsil ettiği ileri sürülebilir.

Eko hem mitostaki dönüşüm kavramıyla hem de müzik terminolojisindeki anlamıyla bir anlatım biçimini işaret etmektedir. Eko bir ses meselesidir, ses ise doğası bakımdan oldukça ilişkiseldir. Bir kaynaktan doğar ve yayılır, çarptığı yerde bir titreșim oluşturur ve o yere kaynağına ilişkin bilgi taşır. Eko, yankı adı verilen doğal bir fenomendir ve kaynağından çıkan bir sesin, yansıtıcı bir yüzeyden sekerek yeniden işitilmesi durumu anlamına gelmektedir. Bu fenomende sesler mesafe, materyal ve yüzey özellikleri gibi değişkenlere göre yapısal değişikliğe uğrarlar. Bir diğer yandan eko kavramı müzik terminolojisinde sesin eşit aralıklarla ve şiddet olarak giderek azalan bir şekilde, birden fazla sayıda tekrar etmesi anlamına da gelmektedir (Önen, 2007, s. 386). Bu anlamıyla eko, kendisini oluşturan kaynağı vurgulamasıyla bilgi taşıyan bir ortam olduğu ölçüde, ses ile anlatıda seslerin yapısını dönüşüme uğratan kurgusal bir eleman olarak da karşımıza çıkmaktadır. Ses ve yapısının dönüşüme uğraması bağlamında doğal bir fenomen olarak eko kavramının ses manipülasyonun antik atası olduğu fikri de ileri sürülebilmektedir. "Narkissos ve Eko" mitine dönülecek olursa eko adı verilen sesin kaynağından uzaklaşmış, bedenini terk etmiş ve yabancılaşmış, kaynağından uzaklaştığı ölçüde de yalnızlaşmış bir ses olduğu fikri ileri sürülebilir.

Yabancılaşmış ve yalnızlaşmış ses düşüncesi, sesin ve sesi oluşturan kaynağın birbirlerinden ayrılması anlamına gelmektedir. Bu anlamıyla kaynağın ve kaynağa ait seslerin ayrıştırılması düşüncesi, 1960'lı yıllardan beri yaygınlaşarak bir üretim mecrasına dönüşen ses sanatının problemi olarak karşımıza çıkmaktadır. Ancak ses ve görüntünün birbirinden uzaklaştırılmasını anlamanın yolu, gerçek anlamıyla bu iki fenomenin ne zaman birbirlerinden ayrıldığının anlaşılmasından geçmektedir. Sanat tarihçisi ve medya kuramcısı Kahn'ın (1999) belirttiği üzere: "Narkissos Eko'dan daha gelișmiş bir teknolojiye sahipti" (s. 8). Kahn burada insanın kendisini dolaysız olarak görebilmesiyle dolaysız olarak işitebilmesi arasındaki teknoloji farkına dikkat çekmektedir. Gerçekten de insanın kendi görüntüsünü görmesi ve kendi sesini işitebilmesi arasında tarihsel olarak büyük bir boşluk bulunmaktadır. İnsan bir su birikintisindeki yansımasını algılayabilecek bilince sahip ilk atasından itibaren kendi görüntüsünü izleyebilmiștir. Ancak insanın kendisini ișitebilmesi, kendisini görebilmesi kadar eskilere uzanamamaktadır.

İnsanın kendisini en dolaysız yoldan görebilmesini mümkün kılan bir materyal olarak ayna ele alınırsa, insanın kendisini izlemeye başlaması milattan önce 6000 yılına kadar uzanmaktadır (Enoch, 2006, s. 775). Ancak buna karşıılık insanın kendisini dış etkilerden bağımsız olarak işitmesi 1877 yılında 'Fonograf' ${ }^{\prime}$ adlı makinenin icat edilmesiyle mümkün olabilmiștir (Kahn, 1999, s. 9). Fonografın icadına kadar sesin kaydı sadece yazı ya da Munch'un Çığllk resminde olduğu gibi metaforik olarak bir sesi ima eden yapıtlarla mümkün olabilmiştir. Fonograf sayesinde bir sesin kaydedilip, aslına sadık bir biçimde yeniden çalınabilmesi sağlanabilmiştir. Bu aşamada bir nesne ve kendisinden çıkan sesin, nesne ortamda olmaksızın sesinin yeniden oluşturulabilmesiyle, görüntü ve sesin ilk kez birbirlerinden gerçek anlamda ayrılabilmiştir. On dokuzuncu yüzyılda ortaya çıkan teknolojik gelişmeler düşünüldüğ̈̈nde fonografın yaptığı türden bir ayrışma, 1876 yılınada telefonun icadıyla da perçinlenmiş olur. Bu teknolojik gelişmeler 1şı̆̆ında, sesin tarihte ilk defa görsel imgenin yerine geçebildiği düşüncesi de ortaya çıkmıştır (Licht, 2007, s. 4)

Fonografın icadı sanat dünyasında fotoğraf makinesi ile aynı etkiyi yaratmıştır. İlk kez fonograf sayesinde bir ses olduğu gibi kaydedilebilmiş, böylece sesin tekrar çalınabilmesi, analiz edilip yeniden yorumlanabilmesi ve hatta durdurulabilmesi mümkün olmuştur (Schafer, 2006, s. xii). Fonograf sayesinde ortaya çıkan bir diğer faktör de radyo frekansları, elektrik statiği ve endüstriyel sesler gibi normalde işitilemeyen seslerin kayı aracıllğıyla ortaya çıkmış olmasıdır. Böylece fonograf aracılığıyla ortaya çıkan bu yeni sesler, müzik ve görsel/plastik sanatlar alanından sanatçıların, ses konusunu geleneksel yaklaşımlardan farklı şekillerde ele almasına sebep olmuştur. 1930'lu yıllardan itibaren ses kayıt ve iletişim teknolojilerin yaşanan teknolojik gelişmelerle birlikte yeni bir ses algısı ve konsepti oluşmuştur. Bu gelişmeler sonucunda John Cage, Edgard Varese ve Pierre Schaeffer gibi avangard besteciler ve sanatçıların katkılarıyla ses, klasik Batı müziğiyle olan bağını kopartarak özgürleşmiş ve yeni bir sanatsal mecra olarak tanımlanmıştır. Bu aşamadan itibaren ses, gürültü ve sessizlik gibi olguları da içine alan, kavramsal, görsel ve üç boyutlu plastik açılımları olan sanatsal bir mecraya dönüşmüştür.

Sesin oluştuğu kaynaktan uzaklaşarak görsel bir imgenin yerine geçebilmesi düşüncesinden hareketle, ekonun bedenini terk etmiş ve yabancılaşmış, kaynağından uzaklaştı̆̆ ölçüde de yalnızlaşmış bir ses olduğu fikri ileri sürülmüștür. Bu haliyle yankı anlamına gelen ekonun yalnızlık kavramıyla ilişkilendirilmesi yalnızca fiziksel özellikleriyle sınırlı kalmayıp, doğrudan bir yalnızlık hikayesi ve kelimenin kökeni olan "Narkissos ve Eko" mitine olan referansıyla da ilişkilidir. Günümüz sanatından ortamı ses olan ve farklı yönleriyle yalnızlık temasını işleyen üç örnek aşağıda incelenmiş̧tir. Bu yapıtlar yalnızlık konusunu farklı içeriklerde ele almalarına rağmen, eko hem

${ }^{1}$ Fonograf (eski Yunanca fone, "ses" ve grammein, "yazmak") köklerinden gelen, ses kayıt ve tekrar dinleme olanakları veren cihazadır. 1877 yılında Thomas Edison tarafından tasarlanmıştır. 
kurgusal-yapısal bir eleman olarak kullanılmış hem de yapıtların deneyimlenmesinde anlatımı oluşturan ve güçlendiren bir öğe olarak benzer biçimlerde ele alınmıştır.

\subsection{Susan Philipsz'in Lowlands'i ve bireyin yalnızlığı}

Lowlands İskoç sanatçı Susan Philipsz'e ait bir ses enstalasyonudur ve Philipsz bu yapıtıyla 2010 yılında Turner Prize ödülünü kazanmıştır. Yapıt ismini on altıncı yüzyıla ait bir halk şarkısı olan Lowlands Away adlı eserden almakta ve sevdiği insanı kaybeden bir kişinin yasını konu edinmektedir. Denizcilikle ilgili olan bu şarkı İskoç, İngiliz ve Amerikan denizciler tarafından farklı ancak benzeşen içeriklerde ele alınan bu şarkı gemi güverteleri ve rıhtımlarda söylenmiştir (Zierke, 2018). Philipsz, Lowlands adlı yapıtını şarkının İskoç versiyondan yola çıkarak oluşturmuştur. Hikâyeye göre denizci bir sevgilisi olan kadın, sevgilisinin uzak denizlere yaptığı seferden dönmesini beklemektedir, uzun ve sonuçsuz bekleyişinin ardından kadın bir gece rüyasında sevgilisini bir hayalet olarak görmüş ve sevgilisi ona boğulduğunu ve artık geri dönemeyeceğini söylemiştir.

Philipsz bir halk şarkısından esinlendiği bu eserini İskoçya'da yaşadığı tesadüfi bir karşılaşmanın ardından hayata geçirmiştir. Sanatçı Lowlands adlı bu ses enstalasyonu İskoçya'nın Glasgow kentindeki Clyde nehri üzerinde yer alan üç köprünün altına yerleştirmiştir. Bu köprüler sırasıyla Caledonian Köprüsü, Glasgow Köprüsü ve George V köprüsüdür. Philipsz Lowlands için neden özellikle bu köprüleri tercih ettiğini şu sözleriyle ifade eder: "Caledonian köprüsü üzerinde yürüyüş yaptığım sırada yere bırakılmış bir demet çiçeğe takılarak tökezledim, daha sonra çiçeklerin köprüden atlayarak intihar eden bir genç için bırakıldığını öğrendim” (Amar, 2010). Lowlands Away'in boğularak ölen bir kişiyle ilişkili olması ve üzerinde tren istasyonu bulunan bu köprünün oldukça aktif bir kamusal olan olması sebebiyle Philipsz enstalasyonunu Caledonian ve devamındaki iki köprünün altına da yerleştirmeye karar verdiğini ifade etmiştir.

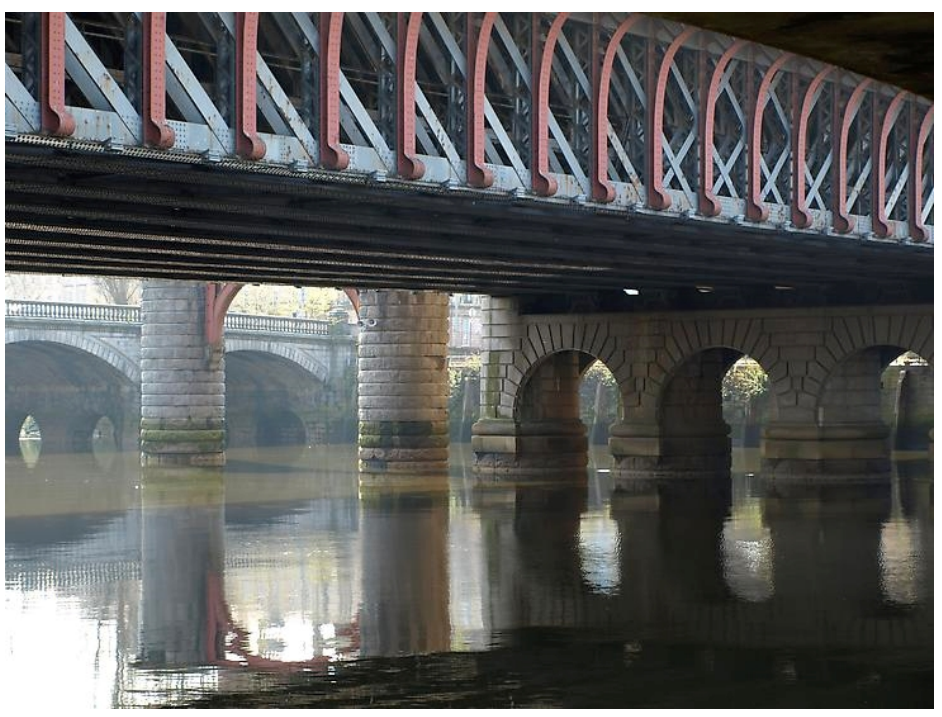

Resim 1. Susan Philipsz, "Lowlands”, 2010

Lowlands adlı yapıt yirmi dakikadan oluşan bir ses kurgusudur ve Lowlands Away'in sözleri sanatçının kendisi tarafından okunmasıyla oluşturulmuştur. Philipsz şarkının sözlerini neden kendisinin okuduğunu şu ifadeleriyle açıklar:

“Konuşma sesimi hiç beğenmiyorum. Bir şarkıya doğru tondan eşlik edemiyorum, bu eksikliğim de aslında yapıtlarımın güçlü tarafını oluşturuyor. Bana göre herkes insan sesini tanır, bir parçaya eşlik edemeyen ya da yanlış tondan okuyan bir kişiyi duyduğunuz anda hemen fark edersiniz ki, bu da geçmişiniz ve hatıralarınızla anında güçlü bir bağ kurmanızı sağlar (Corner, 2010).

Philipsz bu ifadeleriyle sesin ilişkiselliğine vurgu yaparken aynı zamanda topluluk karşısında beceriksizce şarkı söylemenin pek çok kişide yarattığı kendini yalnız hissetme veya utanma gibi duyguları anında çağrıştırabildiğine dikkati çekmektedir. Sanatçı burada sesi bireysel geçmişi hızla çağrıştıran bir araç olarak ele almakta ve sesin fiziksel özelliklerini, eseri deneyimleyen kişilerde yalnızlık hissini çağrıştıracak şekilde kullanma yolunu tercih ettiğini belirtmektedir. Lowlands yalnızlık temasını işleyen bir yapıttır. Burada yalnızlık sevilen bir varlığın kaybedilmesi biçiminde, hayatın akışı içinde karşılaşılan türden bir yalnızlık olarak ele alınmıştır. Philipsz köprüyü yalnızca Lowlands Away’deki hikayeyle köprüden atlayarak boğulan gencin tesadüfi benzerliği sebebiyle değil, aynı zamanda ses yerleştirmesin etkisini artırması açısından da seçmiştir. Köprü altları yapısal özellikleri sebebiyle sesleri amplifike eder ve aynı zamanda da yankıya sebep olurlar. Bu bilinçli tercih sebebiyle de eko bu yapıtın yalnızca doğal bir sonucu değil hem enstalasyonun kurgusal bir öğesi hem de anlatıyı güçlendiren bir araçtır. 
Lowlands yerleştirildiği mekanlarda belirli aralıklara çalmaktadır, köprülerin yakınında oturan, altından ya da üzerinden geçen kişiler beklemedikleri bir anda, merkezi belli olmayan ve her yerden gelen yumuşak bir sesi deneyimlerler. $\mathrm{Bu}$ ses deneyimleyenlere adeta ben buradayım ve yapayalnızım mesajını iletir. Bu șekliyle Lowlands'in yankıları tıpkı Narkissos mitinde olduğu gibi Eko'nun kendi varlığını çevresine hatırlatmak için sesleri tekrar etmesine benzemektedir. Philips Lowlands için: "Çalışmamın, eksiklik ve özlem duygusunu uyandırmasını istiyorum, beklenmedik ve her yerden yankılanarak gelen bu ses, izleyicinin kendi anıları ve duygularıyla yeniden bağlantı kurmasına yardımcı oluyor" diye belirterek kamusal alandaki bu karşılaşmanın yalnızlıkla olan bağını ifade etmiştir (Halsey, 2010).

Lowlands hayatta değer verilen bir varlığın yitirilişinden kaynaklanan yalnızlık durumunu farklı zaman dilimlerine göndermeler yaparak çeșitli katmanlarda işlemiş bir yapıttır. Esere ismini veren Lowlands Away şarkısı yalnız kalmış bir bireyi işaret ederken Philipsz'in sesi de folklorik bir anlatıya referans vermektedir. Bir diğer katmanda ise Caledonian köprüsünde gerçekleşen intihar vakası yer almaktadır, bu olay da kamusal alanda gerçekleşen yakın tarihli gerçek bir kayıptır. Philipsz bu yapıtıyla pek çok insanın birbiriyle etkileşim içinde bulunduğu köprü civarlarında ortaya çıkan ve nereden geldiği pek de anlaşılamayan detone seslerin yankılanarak dinleyicileri kuşatması fikriyle, onları kendi kayıpları ve anılarıyla buluşturarak anlık bir yabancılaşma ve yalnızlık duygusunu yaratmayı hedeflemiştir.

\subsection{Anke Eckardt'ın Between $\mid$ You $\mid$ and $\mid M e$ 'si ve toplumsal yalnızlık}

Alman sanatçı Anke Eckardt'a ait olan Between $\mid$ You $\mid$ and $\mid$ Me ana malzemesi ses olan çoklu-duyusal (multisensory) olan ortam odaklı bir ses yerleştirmesidir ve 2011 yılında CYNETART kapsamında Dresden, Almanya'da gerçekleştirilmiştir. Enstalasyon altı adet hipersonik hoparlör, dört projektör, iki sis makinesi ve akustik yalıtım malzemesi ve bu ekipmanın yerleştirildiği karanlık bir mekândan oluşmaktadır. Yerleştirmede kullanılan hipersonik hoparlörler hem kavramsal hem de teknik olarak çalışmanın temelini oluşturmaktadır. $L R A D$ olarak tanımlanan bu hipersonik hoparlörler 'Uzun Menzilli Akustik Tertibat' (Long Range Acoustic Device) anlamına gelen, asker ve polis tarafindan toplumsal olaylara müdahalede kullanılan, ölümcül olmayan silah kategorisindeki teçhizattır (Wilson, 2018). LRAD sistemi içinde bulunan hoparlörler ses dalgalarını tıpkı bir lazer ışını gibi doğrusal bir biçime sokarlar, formu değişen ses dalgaları herhangi bir yüzeye temas edene kadar neredeyse işitilemez bir hal alırlar. $L R A D$ tarafindan yönlendirilen bu ses demeti herhangi bir yüzeye çarptığında ise temas ettiği yüzeyde işitilebilir hale gelir. LRAD $8 \mathrm{~km}$ mesafeye kadar $160 \mathrm{db}$ şiddetinde bir ses sinyali gönderebilecek kapasiteye sahip olup, cihazın gönderdiği seslere maruz kalanların hareketsiz kaldığı, bayıldığı ve gelen emirlere koşulsuz itaat ettikleri bilinmektedir. LRAD teknolojisi sözü edilen etkisi sebebiyle çeşitli toplumsal olaylarda denenmiş olup 2009 yılında Amerika, Pittsburg'da gerçekleştirilen G-20 zirvesini protesto eden göstericiler üzerinde tam kapasiteli olarak kullanılmıştır (Eckardt, 2011).

Eckardt, Between $\mid$ You $\mid$ and $\mid$ Me adlı yapitında $L R A D$ hoparlörlerini kullanarak siyasi otoriteyi ve toplumsal ayrışmayı işaret eden bu silahı yaratıcı bir şekilde yeniden kurgulayarak işlev ve anlamını dönüştürmüştür. Toplumsal olaylara müdahale amacıyla kullanılan bu silah bir bakıma egemen ideolojinin karşıt görüşleri ne dereceye kadar dinleyip değerlendirdiğinin de göstergesi olarak değerlendirilebilir. Tam da bu noktada ortaya bir yabancılaşma ve yalnızlaşma durumu çıkmaktadır. Burada yalnızlık, bireyin tek başınalığı ya da sosyal ortamından yalıtılması değil, aksine siyasi muktedirin ya da toplumun genelinin belirlediği normlar dışında kalarak ötekileşen çoğulcu bir yalnızlıktır. $L R A D$ toplumun genelinden farklı görülen kişileri ötekileştiren, dışlayan ve düşman haline getiren tek yönlü bir ideolojinin aygıtı olarak gruplar arasına sınır çekmektedir. Bir bakıma çekilen bu sınır dinlemeyi ve diyalogu anlamsız kılmakta; kişiler, farklı sosyal gruplar, toplumlar ve kültürler arasında aşılması zor duvarların örülmesine neden olmaktadır. Yapıtın adı olan Between $\mid$ You $\mid$ and $\mid$ Me ifadesi ve kelimeler arasında yer alan dikey çizgiler sözü edilen sınırları vurgulamak amacıyla sanatçı tarafından özenle seçilmiştir. Buradan hareketle Eckardt yapıtını bir soru sorarak tartışmaya açmaktadır: "Aramızdaki bu duvarlar ne zaman yükseldi" (Eckardt, 2011). Sanatçı burada Berlin Duvarı, İsrail - Filistin sınıındaki duvar ve A.B.D - Meksika sınıındaki gibi gerçek anlamıyla sosyal gruplar arasına inşa edilen duvarları kastetmektedir.

Eckardt bu çalışmasında duvar metaforu üzerinden sosyal, ulusal ve politik olarak ötekileştirilen, sosyal olarak yabancılaşıp yalnızlaştırılan gruplara bakışımıza karşı alternatif bir okuma sunmaktadır. Bilindiği üzere duvar katı, sağlam ve geçirimsiz bir yapıya sahiptir, kişiyi dış etkilerden koruduğu ölçüde dış dünyayla olan iletişimini de kesmektedir. Eckardt çalş̧masında görünmez bir ses duvarı inşa etmiştir. Hipersonik hoparlörler belirlenmiş mekânda tavadan zemine bakacak şekilde yerleştirilmişlerdir. Hoparlörlerin karşısına sesi emecek paneller konumlandırılmış ve hoparlörlerin yerini belli etmek için projektörler ve 1şık kaynaklarına sis verilmiştir. Eseri deneyimlemek isteyen bir izleyici elini ya da bedeninin herhangi bir bölümünü ışık ve sis katmanının içinden geçirdiği anda sanki duvarı yıkıyormuşçasına yüksek şiddetli bir cam kırılma sesi işitebilmektedir. Hipersonik hoparlörler mekâna durmadan kırılma sesleri yansıtmakta ancak sesler yalnızca bu sanal duvar ile etkileşime girildiğinde bedenin uzuvları üzerinden yansıyarak işitilebilmektedir. 


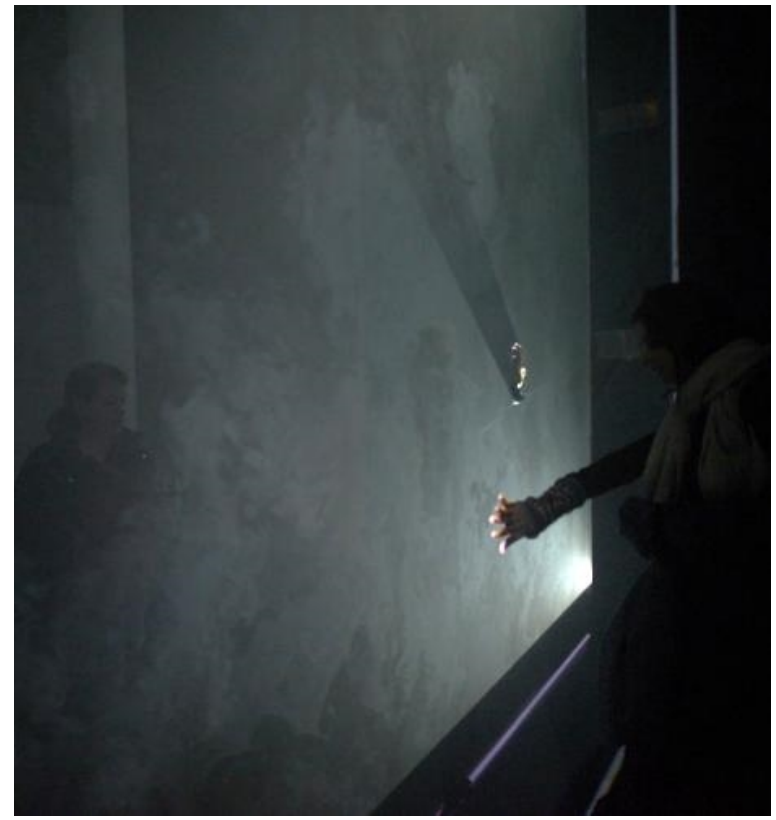

Resim 2. Anke Eckardt, "Between You and Me", 2011

Eckardt bu yerleştirmesiyle mekânda bir duvar inşa etmiştir. Bu duvarla etkileşime girildiğinde işitilen kırılma sesi, gerçek bir duvarın katılığı ve geçirimsizliğine karşın kolaylıkla aşılabilen, dayanıksız ve geçirgen bir yapıdadır. Bu ses yerleștirmesi izleyicisini duvarın dıșına çıkmaya davet ederken ötekiyle aramıza çekilen sınırları kaldırmamızı ve empatiyle dinlemenin önemini vurgulamaktadır. Eckardt katılımcı politikaların geliştirilmesi ve demokratik toplum anlayışının yerleştirilmesini önerirken, görmezden gelinen ve yalnız bırakılmış toplumsal gruplara olan bakışımızı, bu sınırı yaratan mekanizma ve aygıtları kullanarak eleştirmektedir.

Between $\mid$ You $\mid$ and $\mid$ Me adlı yapıt gerek yalnızlığı tema olarak işlemesi gerek de yalnızca yankının bir sonucu olarak deneyimlenebilmesi sebebiyle Eko'nun yalnızlığı bağlamına oturmaktadır. Enstalasyonda yer alan sesler kırılan bardak, tabak ve kâse gibi gündelik nesnelerin sesleridir ancak temsil ettikleri gerçeklik daha geniş bir düzlemde gündelik yaşamı oluşturan sosyal dinamiklerdir. Kendilerini oluşturan nesnelerden farklı bir düzlemi işaret eden bu sesler, yalnızca bir yüzeyden yani katılımcıların bedenlerinden yankılanarak oluşabilmektedir. Bu sebeple de izleyiciler sesten oluşan bu duvarın ötesine geçmek koşuluyla varlık gösterebilecek ve ben de buradayım ve katılıyorum diyerek yalnızlıklarını ve yabancılıklarını aşabilecektir. Bu haliyle izleyicilerin bedenleri aracılığıyla sesleri deneyimleyebilmesi "Narkissos ve Eko" mitindeki bedenini yitirmiş ses düşüncesiyle bağlantı kurmaktadır, burada beden olmadan sesin bir anlamı yoktur çünkü sesler işitilemez durumdadırlar. İzleyiciler kendilerini duvarlar arasına izole etmek yerine duvarları aşmayı tercih ettiklerinde ise yapıttaki sesler ortaya çıkmakta, metaforik olarak da sosyal çevreye entegre olmaktadırlar. Bedenin aktif katılımıyla seslerin anlamına kavuşması fikri Eko'nun kaybettiği bedenine sesler aracılığıyla yeniden kavuşmasına da benzetilebilir.

\subsection{Embodied Media’nın Eremocene’i ve bir tür olarak insanın yalnızlığı}

Embodied Media Avustralyalı sanatçı Keith Armstrong tarafindan yürütülen ve sürdürülebilir bir geleceği tasarlamayı hedefleyen disiplinlerarası araştırmacılardan oluşan bir sanat kolektiftir. Eremocene - The Age of Loneliness (Eremocene - Yalnızlık Çağı) adlı bu yapıt Armstrong ve Avustralyalı sanatçılar Luke Lickfold, Matthew Davis tarafindan 2017 yılında Avusturya'da gerçekleştirilen Ars Electronica festivalinde sergilenmiştir. Çalışma sekiz farklı kanal sesi veren sekiz ayrı hoparlörden ve çeşitli elektronik aygıttan oluşan bir multimedya yerleştirmesidir. Eremocene - Yalnızlık Çağı adını Eremocene kavramını 2014 yılında The Meaning of Human Existence adlı kitabında ilk kez kullanan biyolog Edward O Wilson'dan almaktadır. Eremocene Antik Yunan dilinde yalnız, ıssız, terkedilmiş anlamına gelen 'eremos' kelimesinden türetilmiştir (Thayer ve Smith, 1999). Wilson (2016), Eremocene kavramını eleştirel bir şekilde kullanarak, insan türünün diğer türleri yok etmeye devam ettiği müddetçe yalnızlığa mahkûm olacağını belirtmek için bu çağa Antroposen ${ }^{2}$ çağı değil de Eremocene ya da yalnızlık çağı adının verilmesi gerektiğini ifade etmektedir. Half Earth adlı kitabında insan türünün dünyadaki biyoçeşitlilik üzerindeki etkisinden bahsederken, insanın anlık ihtiyaçlarını gidermek uğruna ekosistemi bir yok oluşa mı sürükleyeceğini yoksa gelecek nesiller için kitlesel yok oluşun önüne mi geçeceği sorusunu tartışmaya açar. Wilson insanın ekosistemi yok etme yolunu seçtiğinde bizi bekleyecek olan durumu şu

\footnotetext{
${ }^{2}$ Antroposen, jeolojik zaman cetvelinde insan türünün yerküreye etki etmeye başladığı düşünülen devredir. Bu etkinin en üst düzeye çıktığı Sanayi Devrimi'nden başlayarak bugüne halen devam ettiği ileri sürülen döneme verilen isim.
} 
şekilde ifade eder: "Bu durumda Eremocene yalnızca insanlar, evcilleştirilmiş bitkiler ve hayvanlar ile göz alabildiğince tarlalardan oluşan bir çağdan ibaret olacaktır” (s. 20). Bu ifadesiyle yazar insan nüfusu, ihtiyaçları ve dünyanın faunası arasındaki hassas dengeyi göz önüne sermekte ve eğer bir önlem almazsak diğer canlıları tarihten silerek yeryüzünde yalnızca kendi türümüz ve ihtiyaçlarımızla ilgili canlıların kalacağını ve bir tür olarak yalnızlığa mahkûm olacağımızı böylece de insanın yok olabileceğini ileri sürer. İnsanın evrimsel serüveni düşünüldüğünde, türümüz tarihte ilk kez Afrika'dan başlayarak dünyanın diğer coğrafyalarına yayılmış ve yerleşilen bu yeni yerlerde ekosistemi geri döndürülemeyecek ölçüde değiştirmiştir. Harari (2012)'nin de ifade ettiği gibi tarihsel kayıtlar Homo Sapiens Sapiens'in bir ekolojik seri katil olduğunu göstermektedir (s. 78).

Eremocene - The age of Loneliness biyolog Pyle (1993)'ün 'extinction of human experience' (insan deneyiminin yitimi) teorisinden de hareket etmektedir (s. 130). Pyle'a göre insan deneyiminin yitimi, evrimsel geçmișe sahip türlerin tarihten silinmesi sonucu biyoçeşitlilik derin bir karanlığa gömüldüğünde, tek başına insan deneyiminin anlamsızlaşacağı fikrine dayanmaktadır. Daha öncede belirtildiği gibi deneyimin kişiler, diğer canlılar ve nesneler arasında paylaşılması yaşamın anlamlandırılmasında bir arada olmanın önemini vurgulamaktadır. Buradan hareketle Eremocene disiplinlerarası etkileşim ve sanatsal bir müdahaleyle insanın bir tür olarak yeryüzünde yalnız kalması düşüncesine yönelik bir farkındalık yaratmayı ve çözüm önerisini eş zamanlı olarak sunmaktadır.

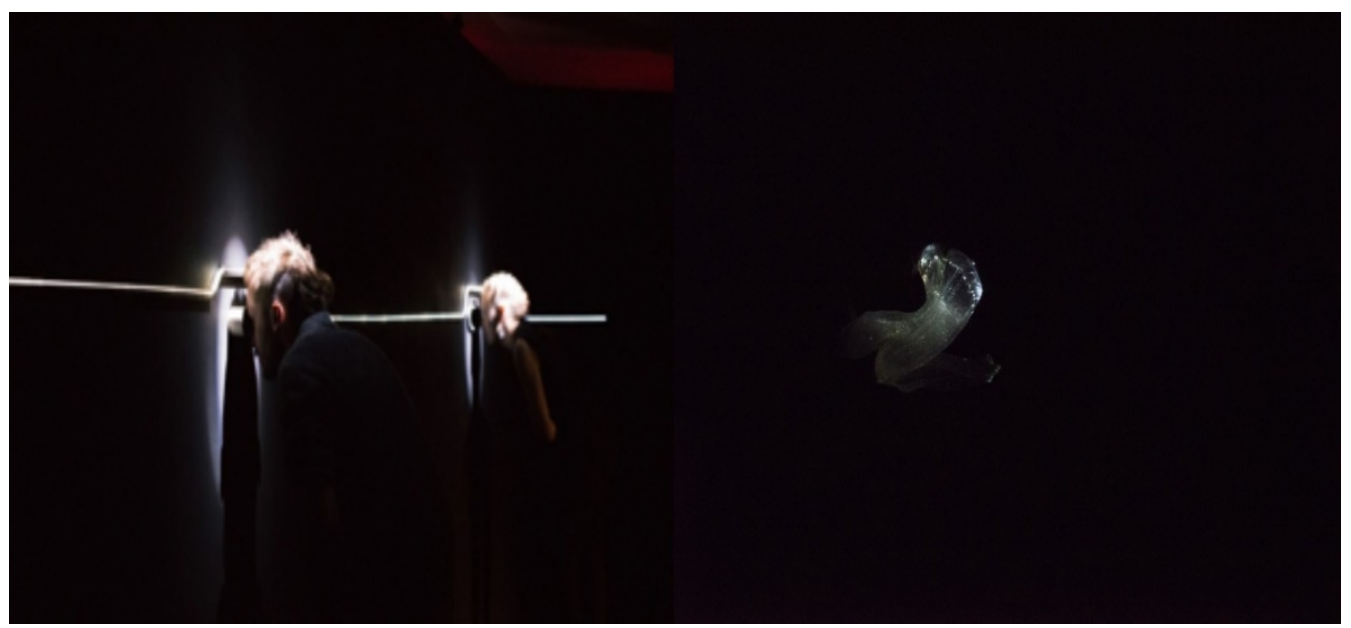

Resim 3. Embodied Media, "Eremocene”, 2017

Eremocene karanlık bir mekân içinde kurgulanmış büyük ölçekli bir yerleştirme olup üç aşamada deneyimlenmektedir. İlk aşama, siyah bir duvarın üzerine yerleştirilen ve etrafı ince bir 1şık demetiyle aydınlatılmış iki adet vizörden oluşmaktadır. İzleyiciler bu vizörler aracılığıyla canlı bir varlığı taklit eden yapay zekalı bir formun, boşlukta süzülerek hareket etmesini, yanıp sönerek 1şıklar çıkarmasını izlemektedir. İkinci aşamada izleyiciler sekiz hoparlörden gelen ve sözü geçen yapay organizmanın hareketlerinden üretilen bir ses kurgusunu dinlerler. Bu kurgu yapay varlıktan çıkan ve eko yaparak baştaki sesi düzenli aralıklarla tekrar eden uzunca bir ses akışından oluşmaktadır. Çalışmanın üçüncü aşaması ise birinci aşamada yer alan formun dijital bir videosu ve canlı olarak üretilen hiperreal görüntüsüyle sesinin aynı anda gösteriminden oluşmaktadır. Yukarıda da belirtildiği gibi yapıt karanlık bir atmosfere sahiptir, kuşkusuz mekânın bu biçimde yalıtılmış oluşu, Pyle'in biyoçeşitliliğin karanlığa gömülmesi düşüncesine yapılan bir göndermedir. Embodied Media kolektifi sürdürülebilir bir geleceği tasarlamak bağlamından hareketle, insanın bir tür olarak yalnız kaldığında varlığını sürdürebilmek adına kendi üretimi, yapay zekalı organizmaları yaratarak yalnızlığına bir çözüm bulabileceği önerisini yapmaktadır. Bir bakıma, bu yaklaşım çift kutuplu bir gelecek vizyonunu ortaya koyar. Bir yanda insan, ekoloji bilinci ve sürdürülebilirlik bağlamında enstalasyonda gösterilen olası bir gelecekten sakınabilir veya diğer yandan geleceği kendi yaratımı yapay organizmalara bağlı bir şekilde devam ettirebilir. Kuşkusuz bu soru bir tür olarak Homo Sapiens Sapiens’in mevcut durum karşısında göstereceği reflekse göre sonucuna ulaşacaktır.

Eremocene bu çalışmanın bağlamı içinde değerlendirildiğine ortaya çıkan yalnızlık fikri, bireysel bir ölçek olmaktan çok bir tür olarak modern insanın varlığını yok oluşa sürükleyebilecek bir tehdit olarak değerlendirilebilir. Burada artık birey değil bir tür olarak insan yalnızdır, daha önce de değinildiği gibi paylaşma deneyimi insanın hayatta kalmak ya da türünü devam ettirebilmek gibi yaşamsal gerekliliklerinden birisidir. Bu bağlamda Eremocene paylaşımın devamı doğrultusunda bir sürdürülebilirliği de işaret etmektedir. Bu yapıt çalışma içinde değerlendirilen diğer yapıtların aksine yalnızca ses odaklı bir proje olmamakla birlikte, eserin deneyimlenme sürecinde ses ve sesin kullanım biçimi yönlendirici bir öğe olarak karşımıza çıkmaktadır. İnsan elinden çıkan yapay canlının tüm hareketleri ses ile doğrudan ilişkili olup, ses kurgusunda karşımıza çıkan eko, bu varlığın vizöre yaklaşıp uzaklaşarak kendisini gösterdiği, bir bakıma izleyiciyle etkileşimde bulunduğu anlarda oluşmaktadır. Bu haliyle değerlendirildiğinde tıpkı Narkissos mitinde olduğu gibi yapay organizma sanal mevcudiyetini gerçek dünyaya yankı vasıtasıyla yerleştirmekte ve ben de varım diyerek etkileşim kurmaktadır 


\section{Sonuç}

İnsan sosyal bir varlıktır, türümüzün evrimsel ve bilişsel serüveni içindeki en büyük başarılarından birisi yalnızca salt zekâsı değil, sosyal iş birliğine olan yatkınlığıdır. Hayatta kalabilmek gibi en temel ihtiyaçlarımızdan, milyonları peşinden sürükleyen ideolojilerin yaratımına kadar pek çok şey bu sosyal iş birliği ve deneyim aktarımı etrafında şekillenmiştir. İnsan tüm bu sosyal etkileşim ağına karşın bir o kadar da yalnız bir varlıktır. Varoluşçulara göre yaşam yalnız deneyimlenir, tıpkı doğum ve ölümün paylaşılamaması gibi. İnsan her şeyden önce vardır ve özünde kendi türdeşlerinden farklıdır, kişi bu ayrımı idrak ettiğinde diğer insanlardan ayrışır ve yabancılaşır dolayısıyla yalnızlaşır. Paylaşılamayan bu varoluşsal yalnızlığın dışında bir de insanın yaşamda deneyimlediği ve başka insanlar ile paylaşabileceği farklı türden yalnızlıklar bulunmaktadır. Bunlar kimi zaman inzivaya çekilmek, sevilen bir varlığı kaybetmek sonucu oluşan yalnızlıklar olabileceği gibi, kimi zaman da toplumsal olarak ötekileştirilmek veya bir tür olarak dünyada grup halinde yalnızlaşmak şeklinde kalabalık gruplar halinde deneyimlenen yalnızlıklar olabilmektedir. Bir deneyim olarak yalnızlığı paylaşılma yollarından birisi de kuşkusuz sanattır, tarih boyunca pek çok sanatçı yalnızlık kavramını farklı içeriklerde ve ortamlarda işlemişlerdir. Bu çalışma kurgusal bir yalnızlık anlatısı olan Narkissos ve Eko'nun hikayesinden yola çıkarak, hikâyenin ana karakterlerinden olan Eko'nun bedenini yitirip yalnızca bir ses olarak varlığını sürdürmesi bağlamında ele alınmıştır. Buradan hareketle bir sesin, kendisini oluşturan kaynaktan uzaklaştırılmasıyla, sesin kendisi ve temsil ettiği bilginin değiştirilebildiği açıklanmış ve söz konusu bu değişimin teknolojik gelişmeler ile birlikte 1960'lı yıllardan itibaren ses sanatı adı verilen bir üretim mecrasını oluşturduğuna değinilmiştir. Çalışmada eko kavramı mitosta olduğu gibi, bedeninden ayrılmış ve yabancılaşmış olan ses, yani kaynak imge ve yayılarak dönüşüme uğrayan sesleri ile müzik terminolojisinde kullanılan anlamıyla ele alınmış ve bu bağlamda yalnızlık temasını işleyen ve malzemesi ses olan çağdaş sanat yapıtları incelenmiştir. Bu çalışmalar bireysel bir yalnızlık hikayesinin işlendiği Susan Philipsz'in Lowlands'i, toplumsal yalnızlığın ve yabancılaşmanın ele alındığı Anke Eckardt'ın, Between $|Y o u|$ and $|M e|$ 'si ve bir tür olarak insanın dünya üzerinde yalnızlaşmasını konu edinen Embodied Media'nın Eremocene'dir.

Söz konusu üç çalışmanın da ortak yanı eko kavramını hem müzik terminolojisi anlamında hem de mitosta ileri sürülen bağlam içinde kullanmalarıdır. Müzik terminolojisindeki anlamıyla eko her üç enstalasyonda anlamı ve anlatımı güçlendiren yapısal bir öğe durumundadır. Philipsz”in Lowlands'inde mekân özellikle eko yapacak şekilde seçilmiş olup, bu yankı etkisinin izleyicileri işin içine çeken bir eleman olduğu sanatçının kendisi tarafından dile getirilmiştir. Anke Eckardt'ın, Between $\mid$ You $\mid$ and $\mid$ Me |'sinde ise yankının, kullanılan teknolojiden kaynaklı olarak yapıtın bedeni etkileşime sokarak deneyimlenmesini sağladığı görülmüştür. Embodied Media'nın Eremocene 'inde ise yankı yapıtta yer alan yapay canlının hareketleriyle doğrudan ilişkili olarak yapıtın izleyici etkileşimine doğrudan bir katkı yaptığı görülmüştür. Bir diğer yandan mitostan hareketle bu üç çalışmada da kullanılan farklı sesler, kendisini yaratan kaynağın bağlamından kopartılarak yalnızlık teması ile ilişkilendirilmiş ve yeni bir bağlam yaratacak şekilde yabancılaştırılmışlardır. Lowlands'de şarkı söyleyen detone bir kadın sesi insanların kendi kayıplarıyla iletişim kurmasını sağlamaya çalışmıştır. Between $\mid$ You $\mid$ and $\mid M$ el'de ise bedenin devreye sokulmasıyla işitilen kırılma sesleri ötekiyle aramızda inşa edilen sınırların kaldırılması gerektiğine dikkat çekmiştir. Son olarak Eremocene'de deneyimlenen seslerin karanlığın içinden yankılanarak mekâna yayılmasıyla sürdürülebilir bir gelecekte yalnız kalmayacağımıza vurgu yapılmıştır. Sonuç olarak Narkissos hikayesinde Eko'nun yalnızlğı yalnızca aşkına karşılık bulamayan bir peri kızının yok oluşa sürüklenmesini değil, sesin kaynağını temsil ettiği ölçüde, ondan koparak farklı bir gerçekliği temsil edebileceği bu bağlamıyla da sanatsal bilgi üretebileceği bilgisine ulaşılmıştır. Ayrıca, fiziksel bir olgu olarak ekonun yalnızca doğal bir fenomen olmadığı, temsil geleneği bağlamında sanatsal bilgi üretmeyi sağlayan bir kavram ve anlatımı güçlendiren yapısal bir eleman olduğu fikri öne sürülmüştür.

\section{Kaynakça}

Amar, A. (2010, 20 Nisan) Susan Philipsz: lowlands@ @ clydeside walkway, The Skinny. Erişim Adresi: https://www.theskinny.co.uk/art/reviews/susan-philipsz-lowlands-clydeside-walkway

Corner, L. (2010, 14 Kasım). The art of noise: 'sculptor in sound' Susan Philipsz. The Guardian. Erişim Adresi: https://www.theguardian.com/artanddesign/2010/nov/14/susanphilipsz-turner-prize-2010-sculptor-insound

Eckardt, A. (2011). Between, you and me. [Blog yazıs1]. Erişim Adresi: http://ankeeckardt.com/?page=41\&lang=1

Enoch, J. M. (2006). History of mirrors dating back 8000 years. Optometry and Vision Science, 83(10), 775-81. doi: 10.1097/01.opx.0000237925.65901.c0

Gençtan, E. (1996). Varoluş ve psikiyatri. İstanbul: Remzi Kitabevi.

Halmos, P. (1969). Solitude and privacy, A study of social isolation, its causes and theraphy. New York: Greenwood Press, Publishers. 
Halsey, G. (2010, 13 Ekim). An artist whose work 'sounds like stars'. New York Times. Erişim Adresi: https:// www.nytimes.com/ 2010/10/14/arts/14iht-rartsound.html

Harari, Y. N. (2012). Hayvanlardan Tanrllara Sapiens Insan Türünün Kısa Bir Tarihi. Genç, Ertuğrul (Çev.). 2015. İstanbul: Kolektif Kitap.

Kahn, D. (1999). Noise, water, meat: A history of sound in the arts. MA: MIT, Cambridge.

Kalınbayrak, N. (2011). Yalnızlı̆̆ın çözümlenmesi (Yüksek Lisans Tezi). Hacettepe Üniversitesi, Ankara. YÖK tez veri tabanından erişildi (Tez No. 308444).

Licht, A. (2007). Sound art: Beyond music, between categories. New York: Rizzol International Publications.

Zierke, R. (2018). Lowlands (Away). [Blog yazıs1]. Erişim Adresi: https://mainlynorfolk.info/anne.briggs/ songs/lowlands.html

Önen, U. (2007). Ses Kayıt ve Müzik Teknolojileri. İstanbul: Çitlembik Yayınları.

Pyle, R. (1993). The thunder tree: Lessons from an urban wildland. New York: The Lyons Press.

Schafer, R. M. (2006). Foreword. J. F. Augoyard \& H. Torgue (Ed.), in Sonic experience: A guide to everyday sounds (p. xii). Montreal: McGill Queen's UP.

Thayer and Smith (1999). Greek Lexicon entry for Eremos. The NAS New Testament Greek Lexicon. Erişim Adresi: https://www.biblestudytools.com/lexicons/greek/nas/eremos.html

Wilson, T. V. (2018). How LRAD Works. [Blog yazısı]. Erişim Adresi: https://science.howstuffworks.com/lrad.htm

Wilson, O. E. (2016). Half Earth: Our Planet's Fight for Life. NewYork: W.W. Norton \& Company.

Yörükan, T. (2000). Yunan mitolojisinde aşk. Ankara: Türkiye İş Bankası Kültür Yayınları.

\section{Görsel Kaynakçası}

Resim 1. Philipsz, S. (Sanatçı). 2010 Lowlands Away. Erişim Adresi: https://www.tate.org.uk/whats-on/tatebritain /exhibition/turner-prize-2010/turner prize 2010-artists-susan-philipsz

Resim 2. Eckardt, A. (Sanatç1). (2011). Between | You | and | Me. Erişim Adresi: http://ankeeckardt.com/?page $=41 \&$ lang $=1$

Resim 3. Embodied Media. (Sanat Kolektifi). (2017). Eremocene. Erişim Adresi: http://embodiedmedia.com/homeartworks/eremocene-age-of-loneliness 